\title{
Astronomically calibrated ages for geomagnetic reversals within the Matuyama chron
}

\author{
Chorng-Shern Horng ${ }^{1}$, Meng-Yang Lee ${ }^{1}$, Heiko Pälike ${ }^{2}$, Kuo-Yen Wei ${ }^{3}$, Wen-Tzong Liang ${ }^{1}$, \\ Yoshiyuki Iizuka ${ }^{1}$, and Masayuki Torii ${ }^{4}$ \\ ${ }^{1}$ Institute of Earth Sciences, Academia Sinica, P.O. Box 1-55, Nankang, Taipei, Taiwan, R.O.C. \\ ${ }^{2}$ Godwin Institute, Department of Earth Sciences, University of Cambridge, New Museums Site, Pembroke Street, Cambridge CB2 3RS, U.K. \\ ${ }^{3}$ Department of Geosciences, National Taiwan University, 245 Choushan Road, Taipei, Taiwan, R.O.C. \\ ${ }^{4}$ Department of Biosphere-Geosphere System Science, Faculty of Informatics, Okayama University of Science, \\ 1-1 Ridai-cho, Okayama 700-0005, Japan
}

(Received December 7, 2001; Revised April 25, 2002; Accepted May 2, 2002)

\begin{abstract}
We present a magnetostratigraphic record from the western Philippine Sea that is tied to a marine $\delta^{18} \mathrm{O}$ record for the past 2.14 million years. The ages of geomagnetic reversals were astronomically calibrated by tuning the oxygen isotopic stratigraphy, yielding a chronology for the following subchrons: Matuyama/Brunhes boundary, $781 \pm 3 \mathrm{ka}$ (slightly above $\delta^{18} \mathrm{O}$ Stage 19.3); top of the Santa Rosa polarity interval, $920 \pm 2 \mathrm{ka}$ (Stage 23/24); base of the Santa Rosa polarity interval, $925 \pm 1 \mathrm{ka}$ (Stage 24); top of the Jaramillo subchron, $988 \pm 3 \mathrm{ka}$ (Stage 27); base of the Jaramillo subchron, $1072 \pm 2 \mathrm{ka}$ (Stage 31); top of the Cobb Mountain subchron, $1173 \pm 4$ ka (Stage 35/36); base of the Cobb Mountain subchron, $1185 \pm 5 \mathrm{ka}$ (Stage 36); top of the Olduvai subchron, $1778 \pm 3 \mathrm{ka}$ (Stage 63/64); base of the Olduvai subchron, $1945 \pm 4 \mathrm{ka}$ (Stage 71/72); top of the Réunion II subchron, $2118 \pm 3 \mathrm{ka}$ (Stage 80/81); and base of the Réunion II subchron, $2133 \pm 5$ ka (Stage 81). This astronomically calibrated chronology independently confirms the ages of major reversals in recently published astronomically calibrated polarity timescales for the Matuyama chron. It also provides the first astronomically calibrated dates for the lower and upper reversals associated with the Cobb Mountain and Santa Rosa polarity intervals, respectively.
\end{abstract}

\section{Introduction}

Obtaining high-quality magnetostratigraphic and oxygen isotope records from deep-sea sediment sequences has long been an aim for paleomagnetists and paleoceanographers. As part of the Deep Sea Drilling Project (DSDP) and the Ocean Drilling Program (ODP), hydraulic and advanced hydraulic piston corers have been used to obtain mechanically undisturbed Plio-Pleistocene sediments for paleomagnetic studies. Among the numerous cores recovered in the past two decades, less than $30 \%$ contain clear polarity zonations (Clement et al., 1996), and only a few have yielded long and detailed oxygen isotope records back into the Pliocene (e.g., DSDP Site 607 and ODP Sites 677 and 846; Ruddiman et al., 1989; Raymo et al., 1989; Shackleton et al., 1990, 1995). So far, the most widely referenced Plio-Pleistocene time scale (0-2.6 Ma) derived from astronomically tuned $\delta^{18} \mathrm{O}$ records is from ODP Site 677 (Shackleton et al., 1990), because its age estimates for the last major geomagnetic reversals have been confirmed not only by other independent astronomical ages (Hilgen, 1991) but also by high-precision ${ }^{40} \mathrm{Ar} /{ }^{39} \mathrm{Ar}$ dating on lava flows (Berggren et al., 1995 and references therein). However, ODP Site 677 was not suitable for paleomagnetic analysis, hence the exact stratigraphic positions of the magnetic reversals relative to the $\delta^{18} \mathrm{O}$ record

Copy right(C) The Society of Geomagnetism and Earth, Planetary and Space Sciences (SGEPSS); The Seismological Society of Japan; The Volcanological Society of Japan The Geodetic Society of Japan; The Japanese Society for Planetary Sciences. were inferred from bio- and oxygen isotope stratigraphy of other cores. Moreover, astronomical ages for short geomagnetic events within the Matuyama chron are not well defined for the ODP Site 677 record (e.g., the Réunion, Cobb Mountain and Santa Rosa polarity intervals). Detailed work from the Mediterranean has enabled astronomical calibration of the polarity timescale using magnetostratigraphy and sedimentary cyclicity which can be related to orbitallyinduced climatic fluctuations (Hilgen, 1991; Lourens et al., 1996; Langereis et al., 1997). Again, however, these astronomically calibrated timescales mainly constrain the ages of major polarity intervals. Short polarity intervals in the Matuyama chron remain poorly constrained in terms of their ages.

Here, we present both high-quality magnetostratigraphic and oxygen isotope records for a giant piston core, which provides a first order stratigraphic correlation between geomagnetic reversals and $\delta^{18} \mathrm{O}$ stages, especially for short geomagnetic events during the past 2.14 million years. This work represents the first astronomical calibration of the lower and upper reversals associated with the Cobb Mountain and Santa Rosa polarity intervals, respectively. In addition, we also observed the Australasian microtektite layer (Lee and Wei, 2000) in the studied core. The relationship between the Matuyama/Brunhes boundary (MBB) and the microtektite layer can therefore be used to estimate the lockin depth of remanence acquisition (Burns, 1989; deMenocal 
et al., 1990), which is helpful for evaluating the true stratigraphic position of magnetic reversals relative to the $\delta^{18} \mathrm{O}$ stages.

\section{Core Description}

Giant piston core MD972143 is $10 \mathrm{~cm}$ in diameter and $38 \mathrm{~m}$ long, and was collected from the Benham Rise $\left(15.87^{\circ} \mathrm{N}, 124.65^{\circ} \mathrm{E}\right)$ at a water depth of $2989 \mathrm{~m}$ in the western Philippine Sea during the IMAGES III cruise of the French R/V Marion Dufresne in 1997. The core was cut into 26 sections of $1.5-\mathrm{m}$ length or less. The coring site is above the carbonate compensation depth and near the Philippine archipelago; therefore the sediments consist mainly of olive-brown hemi-pelagic calcareous ooze with intercalated tephra layers of $1-15 \mathrm{~cm}$ thickness. The core top $(0-0.12 \mathrm{~m})$ is void and cracks occur between sub-bottom depths of 0.78 and $0.87 \mathrm{~m}$. A white foraminiferal sandy layer, dominated by reworked microfossils, exists between 32.91 and $33.95 \mathrm{~m}$ (core section 23). In addition, the Australasian microtektite layer was found in this core and has a peak abundance at $15.71 \mathrm{~m}$ (Lee and Wei, 2000).

\section{Experimental Methods}

Paleomagnetic samples were obtained by pressing $7-\mathrm{cm}^{3}$ plastic cubes $(2.2 \mathrm{~cm} \times 2.2 \mathrm{~cm} \times 2.2 \mathrm{~cm})$ into the sediments. A total of 1661 samples were collected sequentially, with gaps between the plastic cubes being minimized. Low-field mass magnetic susceptibility $(\chi)$ and natural remanent magnetization (NRM) were measured on all samples with a Bartington Instruments MS2 system and a $2 \mathrm{G}$ Enterprises superconducting rock magnetometer, respectively. To examine the stability of the remanent magnetization, stepwise alternating field (AF) demagnetization of the NRM was then carried out on 1320 samples using an in-line tri-axial demagnetizer. Demagnetization was performed at thirteen steps to $80 \mathrm{mT}$, with a 5-10 $\mathrm{mT}$ increment between steps. To obtain information on magnetic mineralogy, isothermal remanent magnetizations (IRMs) were imparted to selected samples using an electromagnet, with ten steps up to fields of 1.0 Tesla. In addition, magnetic particles from ten different levels were extracted using a magnetic finger and identified using X-ray diffraction (XRD) with $\mathrm{CuK} \alpha$ radiation (a Siemens D5000 diffractometer was used). Low-temperature measurements were made on selected magnetic extracts using a Quantum Designs Magnetic Property Measurement System by applying a $1 \mathrm{~T}$ field at $5 \mathrm{~K}$, switching the field off and measuring the IRM at $2^{\circ}$ steps during warming from 5 to $200 \mathrm{~K}$. Elemental concentrations of iron oxides were quantified using electron probe micro-analysis (EPMA). A Jeol JXA-8900R system, equipped with wavelength dispersive X-ray spectrometers, was used. Quantitative analyses were conducted using beam conditions of $15 \mathrm{keV}, 10 \mathrm{nA}$, and $1 \mu \mathrm{m}$ for the acceleration voltage, current and beam diameter, respectively. The quantitative data were corrected to calculate oxide compositions, using the ZAF standard calibration method, where the $\mathrm{FeO}$ and $\mathrm{Fe}_{2} \mathrm{O}_{3}$ contents are computed based on the numbers of bi- and tri-valant $\mathrm{Fe}$ cations from the measured total $\mathrm{FeO}$ values (Nenova, 1997).

Surface-dwelling planktic foraminiferal species, such as Globigerinoides sacculifer and G. ruber, have suffered dis- solution to some extent, therefore specimens of a benthic species, Cibicidoides wuellerstorfi, were picked from the size fraction larger than $150 \mu \mathrm{m}$ for oxygen isotope analysis. The sample spacing for $\delta^{18} \mathrm{O}$ analysis is $4 \mathrm{~cm}$ for most samples from the core top to the bottom, excluding tephra layers and the reworked foraminiferal sandy layer. The samples were ultrasonically cleaned to remove adhering fine particles and treated with $5 \% \mathrm{NaOCl}$ to remove organic matter. The cleaned foraminiferal shells were interacted with $100 \%$ phosphoric acid at $70^{\circ} \mathrm{C}$ and their oxygen isotopic composition was measured using a Finnigan Delta Plus mass spectrometer linked with a Kiel automated carbonate-processing device. Mean values from duplicate or triplicate results were calculated and reported with respect to the PDB standard through calibration against the routinely analyzed NBS19 standard $\left(\delta^{18} \mathrm{O}_{\mathrm{PDB}}=2.20 \%\right)$ with a precision of $\pm 0.08 \%$.

\section{Results}

\subsection{Magnetic mineralogy}

IRM results reveal that all samples are nearly saturated at fields of $0.2 \mathrm{~T}$ (Fig. 1(a)), which suggests that the magnetic carriers are dominated by a low-coercivity mineral in the studied sediments. Moreover, XRD analysis on all ten magnetic extracts indicates that magnetite is present (Fig. 1(b)). However, there is a broadening of the magnetite peaks, which suggests that maghemite could also be present (e.g., Cui et al., 1994), possibly as a surficial oxidation product. Despite the clear presence of magnetite in the XRD results, no Verwey transition is evident in low-temperature IRM data (Fig. 1(c)). The Verwey transition can be suppressed by maghemitization of magnetite (Özdemir et al., 1993) or by substitution of Ti into the magnetite lattice (Moskowitz et $a l ., 1998)$. The change in slope in the low-temperature data at $\sim 50 \mathrm{~K}$ (Fig. 1(c)) might indicate the presence of Ti substitution, although this possibility is ambiguous because several other mechanisms can cause changes in magnetization at this temperature (Moskowitz et al., 1998). EPMA results from the magnetically extracted particles enable clarification of these observations (Fig. 1(d)). Analysis of 12 grains indicates that the extracted particles contain a small amount of $\mathrm{Ti}$ and that these grains are partially oxidized, as indicated by the shift of the data away from the titanomagnetite solid solution line and toward a more oxidized composition. Thus, the rock magnetic and EPMA results indicate that a surficially oxidized low-Ti magnetite is the dominant remanence carrier in the MD972143 core.

\subsection{Magnetostratigraphy}

The $\chi$ of 1661 discrete samples ranges from 9 to $253 \times$ $10^{-8}$ (SI), with an average of $65 \times 10^{-8}$ (SI) (Fig. 2(a)). Tephra layers, which occur in two clusters within the sediment sequence, yield the highest values of $\chi$, while the ca. $1-\mathrm{m}$ thick reworked foraminiferal sandy layer has the lowest measured values.

Before AF demagnetization, the NRM declinations and inclinations already display an outline of the magnetozones recorded in the sediment sequence (Figs. 2(b)-(c)). The interval between 0 and $15.60 \mathrm{~m}$ can be readily assigned to the Brunhes normal chron because most samples have positive inclinations. The interval between 15.60 and $38.00 \mathrm{~m}$ is considered to represent the Matuyama reversed polarity 

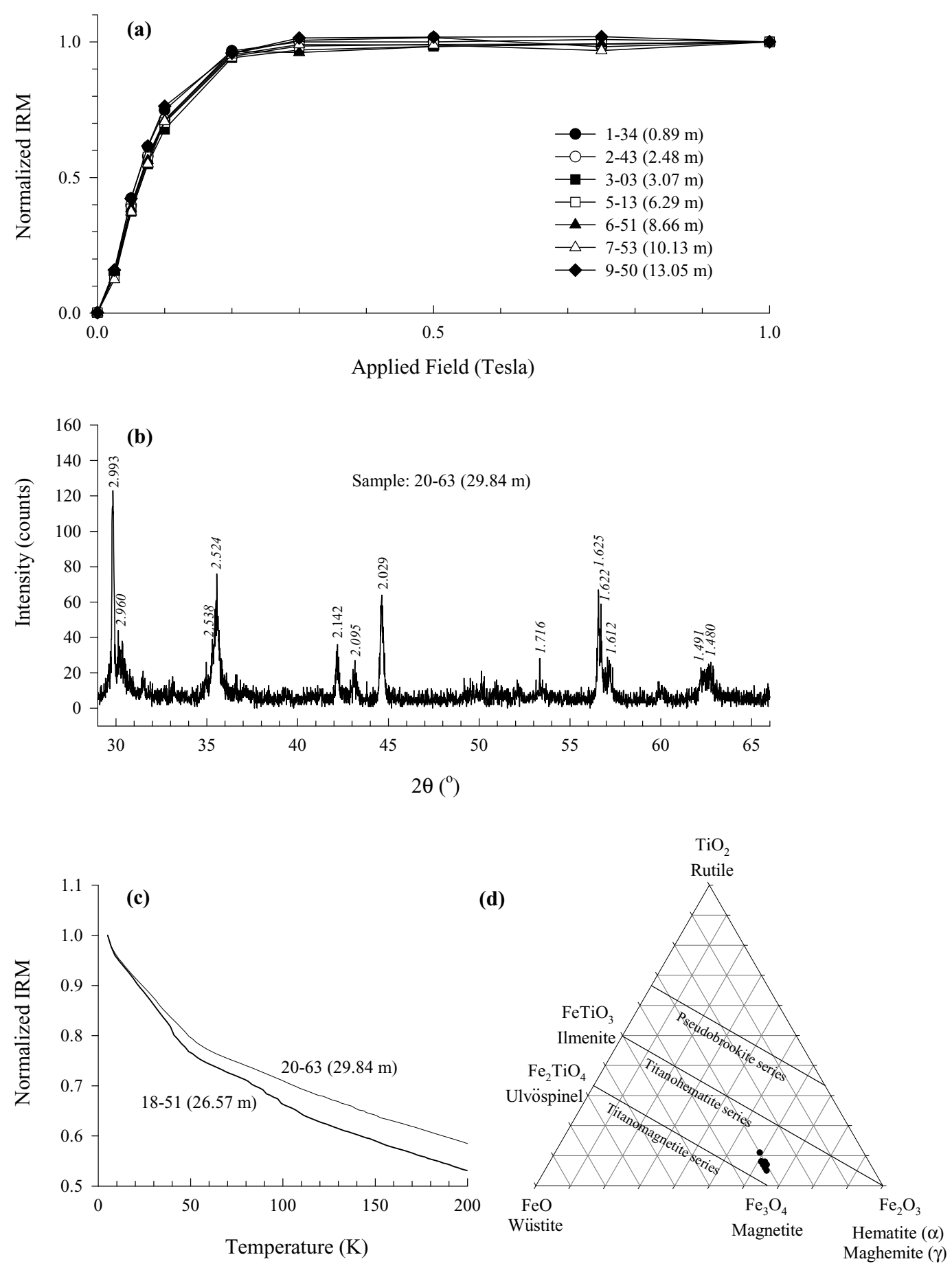

Fig. 1. (a) Representative IRM acquisition curves for samples from core MD972143. All IRMs were normalized by the IRM at 1 Tesla. (b) Representative $\mathrm{X}$-ray diffractogram $(\mathrm{CuK} \alpha$ radiation) for a magnetic extract from $29.84 \mathrm{~m}$. The peaks indicate that magnetite, and possibly maghemite, is present in the sediments. Numbers above the peaks represent $d$-spacings, with italicized values indicating magnetite/maghemite peaks. (c) Low-temperature IRM warming curves normalized to the IRM value at $5 \mathrm{~K}$ for two selected magnetic extracts. (d) Electron probe microanalysis results for 12 grains analyzed from a magnetic extract for sample 20-63 (depth: $29.84 \mathrm{~m}$ ). The results consistently indicate an oxidized low-Ti titanomagnetite.

chron because it is dominated by negative inclinations and is punctuated by several zones with positive inclinations. Corresponding to the polarity changes in inclination, the NRM declinations generally become antipodal during magnetic reversals.

AF demagnetization on the 1320 selected samples was aimed at deciphering the magnetic zonations within the Matuyama chron. During AF demagnetization, the NRMs of $95 \%$ of the samples above the foraminiferal sandy layer
(32.91-33.95 m) showed either a nearly univectorial decay toward the origin of vector component diagrams (Figs. 3(a)(f)) or two significant vector components whose characteristic remanent magnetization (ChRM) can be isolated between 15 and $60 \mathrm{mT}$ (Figs. 3(g)-(h)). However, for some samples, the NRMs are less stable during demagnetization, with more scatter in directions or substantial secondary magnetization components (Figs. 3(i)-(1)). The samples carrying these NRMs are mainly from geomagnetic polarity 
a.

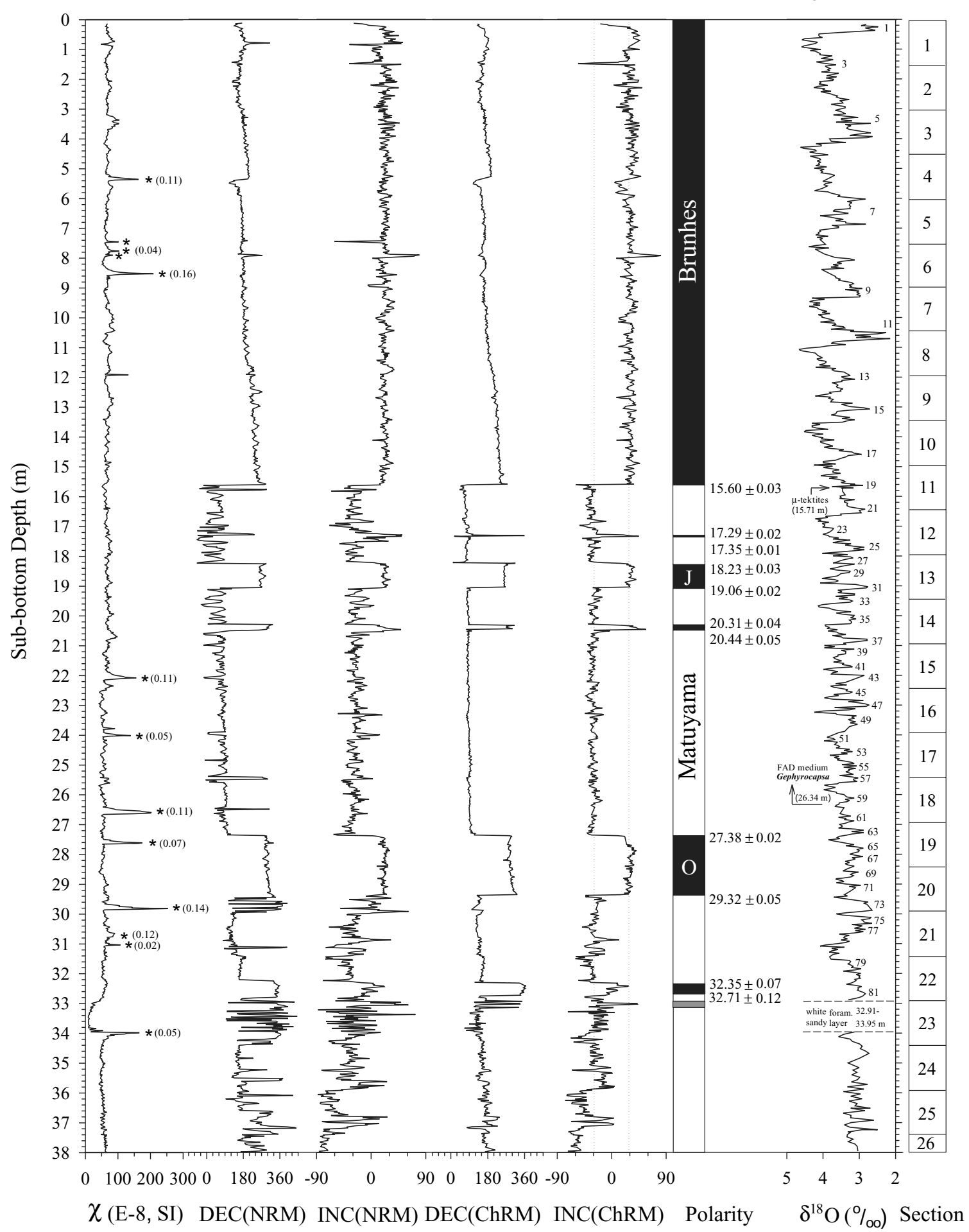

Fig. 2. Plots of (a) low-field mass magnetic susceptibility $(\chi)$, (b)-(e) declinations and inclinations of NRM and ChRM, respectively, (f) magnetic polarities and reversal positions (black: normal polarity; white: reversed polarity), (g) benthic $\delta^{18} \mathrm{O}$ record, and (h) core sections of MD972143 versus sub-bottom depth. Asterisks $(*)$ represent tephra layers and numbers in parentheses indicate thickness of tephra layers in meters. Dotted lines are the expected values $\left( \pm 29.6^{\circ}\right)$ of inclination at the coring site. J and O: Jaramillo and Olduvai subchrons. Gray area: uncertain polarity. The peak abundance of Australasian microtektites, the first appearance datum (FAD) of medium-sized Gephyrocapsa and the reworked white foraminiferal sandy layer are also shown.

transitions. The positions of reversal boundaries were defined by determining the midpoint between the closest samples characterized by stable directions with opposite polarity. The stratigraphic uncertainties of reversal boundaries range from 1 to $12 \mathrm{~cm}$, depending on the thickness of polarity transitions. Although the NRM stability during AF demagnetization decreases below $32.91 \mathrm{~m}$, a poorly recorded short normal polarity interval probably exists between 33.01 


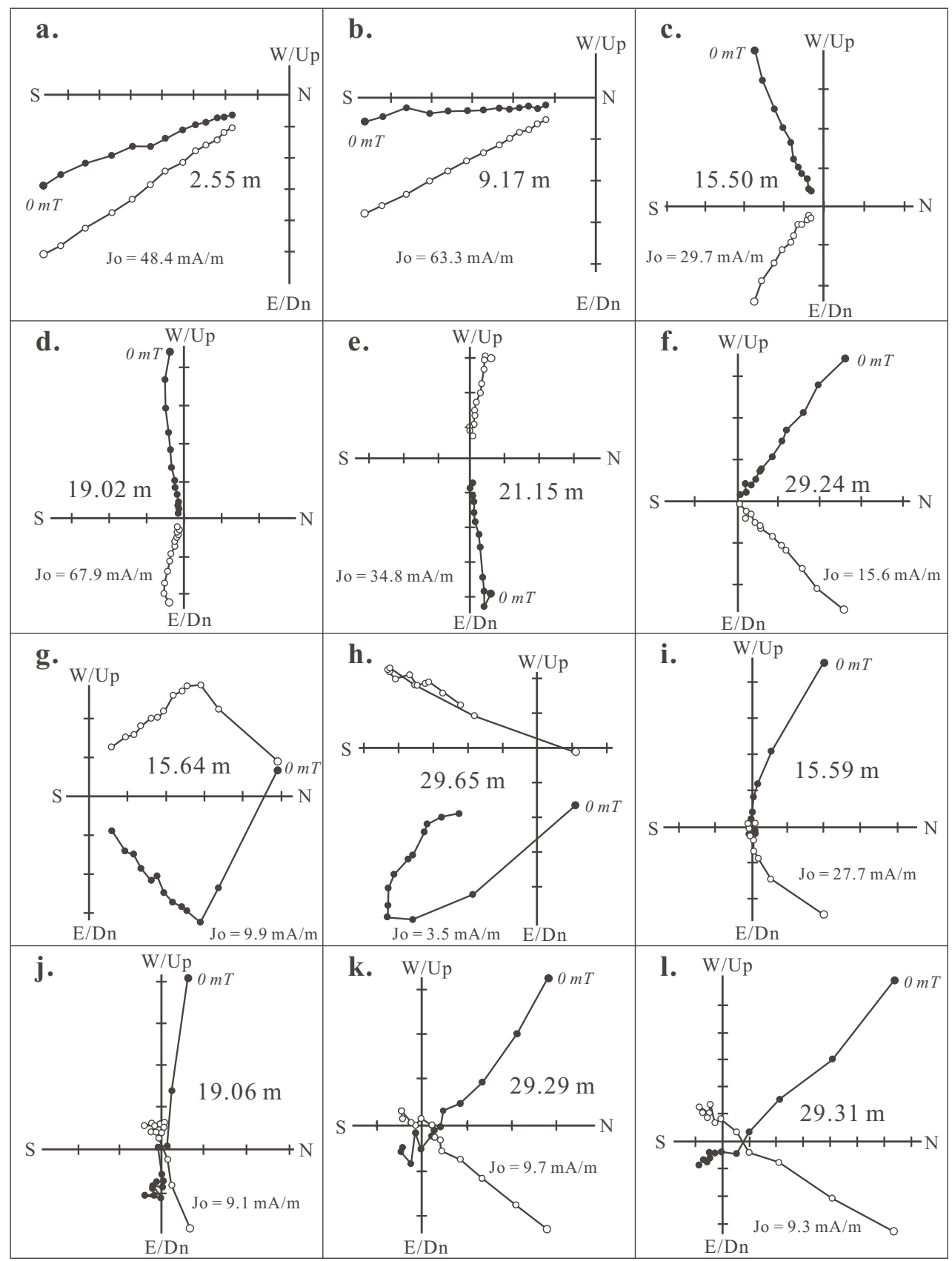

Fig. 3. Representative vector component diagrams of stepwise AF demagnetization results for core MD972143 samples, which show a nearly univectorial decay toward the origin (a)-(f), two significant vector components (g)-(h) and substantial secondary magnetization components (i)-(1). Jo: initial NRM intensity. Solid (open) symbols: projection of vector components onto the horizontal (vertical) plane. Samples were not azimuthally oriented.

and $33.14 \mathrm{~m}$. The instability could be due to the nature of the sediments, which become stiff at these depths, or to redeposition of the foraminiferal sandy layer by slumping, or possible disturbance during coring.

For many of the studied samples, a high-coercivity component remains after AF demagnetization at 60-80 mT (Fig. 3). This high-coercivity component is consistent with the presence of surficially oxidized titanomagnetite, as discussed above, because surface oxidation increases the internal stress and therefore the coercivity of magnetite particles (Cui et al., 1994; Van Velzen and Zijderveld, 1995). Despite the fact that this high-coercivity component is not completely removed by our AF demagnetization treatment, the identified
ChRM component is linear and tends toward the origin of the plots and a straightforward magnetostratigraphy is obtained.

Using all of the ChRM directions in the stable polarity zones and the intermediate directions in the transition zones, as shown in Figs. 2(d)-(e), we constructed the magnetic polarity zonation shown in Fig. 2(f). It is clear from Fig. 2(d) that there are progressive changes in declination, which probably indicate that the sediments have been twisted during core recovery. On the other hand, variations in inclination (Fig. 2(e)) are relatively small for the interval above $32.30 \mathrm{~m}$, except for anomalies at $1.45-1.49 \mathrm{~m}, 7.90-7.97 \mathrm{~m}$, and 30.81-30.90 m. In light of concomitant occurrences of low geomagnetic paleointensities at these levels, the anoma- 

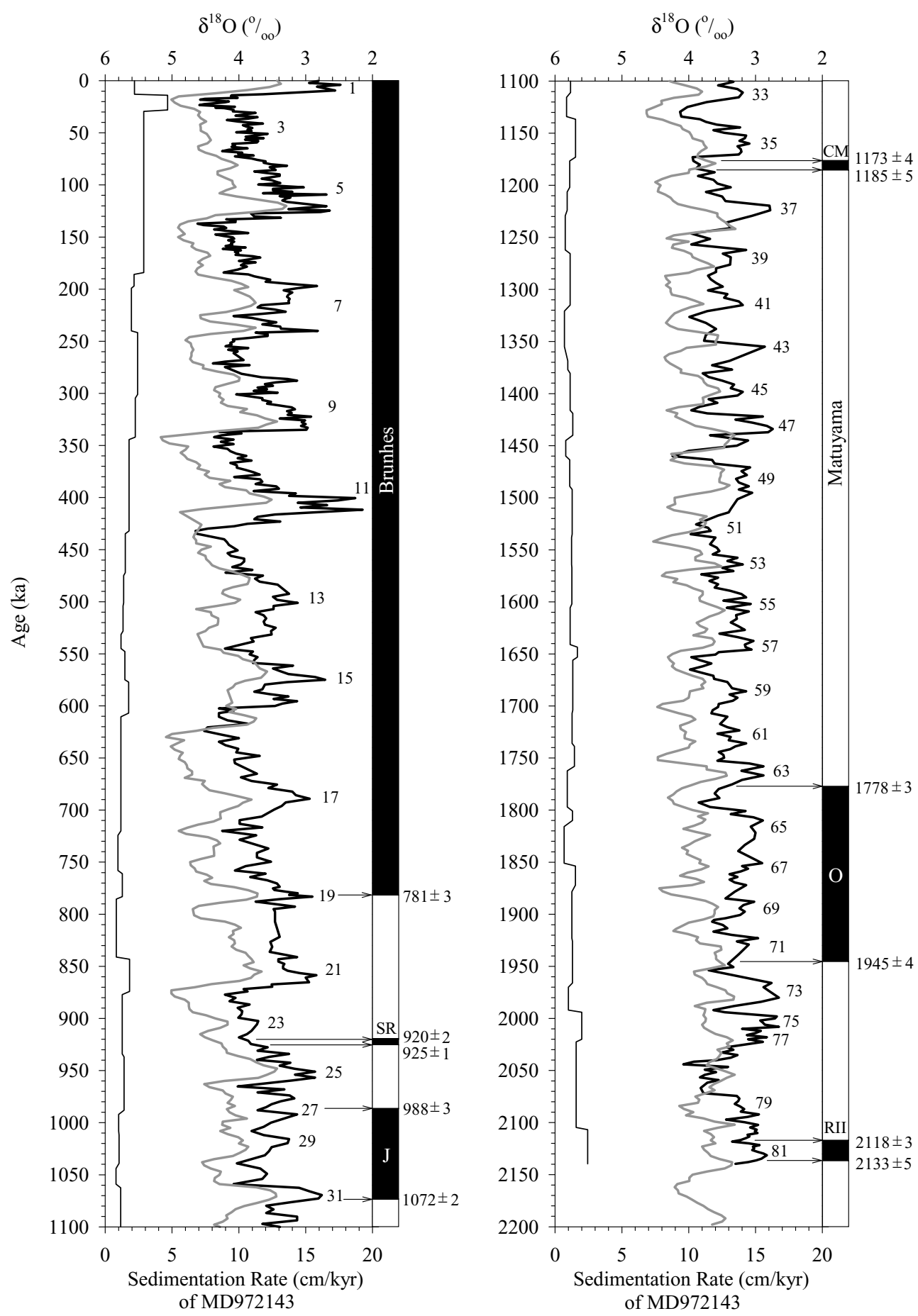

Fig. 4. Age of the $\delta^{18} \mathrm{O}$ record for core MD 972143 (thick solid line) and a comparison with the V677846 reference curve (gray line). The sedimentation rates (thin solid line) of core MD972143 were determined based on linear interpolation between 56 age control points. Ages of magnetic reversals within the Matuyama chron and their relationship with oxygen isotope stages are also shown. SR, J, CM, O, and RII: Santa Rosa polarity interval, Jaramillo, Cobb Mountain, Olduvai, and Réunion II subchrons, respectively.

lies may be related to short geomagnetic excursions (Horng et al., 2002). The average inclinations in the normal and reversed polarity magnetozones are $30.3^{\circ}$ and $-30.7^{\circ}$, respectively, which are not significantly different from the inclination expected for a geocentric axial dipole field at the site latitude $\left( \pm 29.6^{\circ}\right)$.

In summary, core MD972143 records a high-quality magnetic polarity signal since the Matuyama chron (Fig. 2(f)). The two prominent normal polarity magnetozones in core section 13 and sections $19-20$ can be assigned to the Jaramillo and the Olduvai subchrons, respectively. In addition, there are four short normal polarity intervals in the Matuyama chron. The youngest one, which lies between the MBB and the Jaramillo subchron, probably corresponds to the Kamikatsura (Maenaka, 1983; Champion et al., 1988) or Santa Rosa polarity interval (Singer et al., 1999; Singer and Brown, 2002), and the normal polarity episode below the Jaramillo subchron may represent the Cobb Mountain 


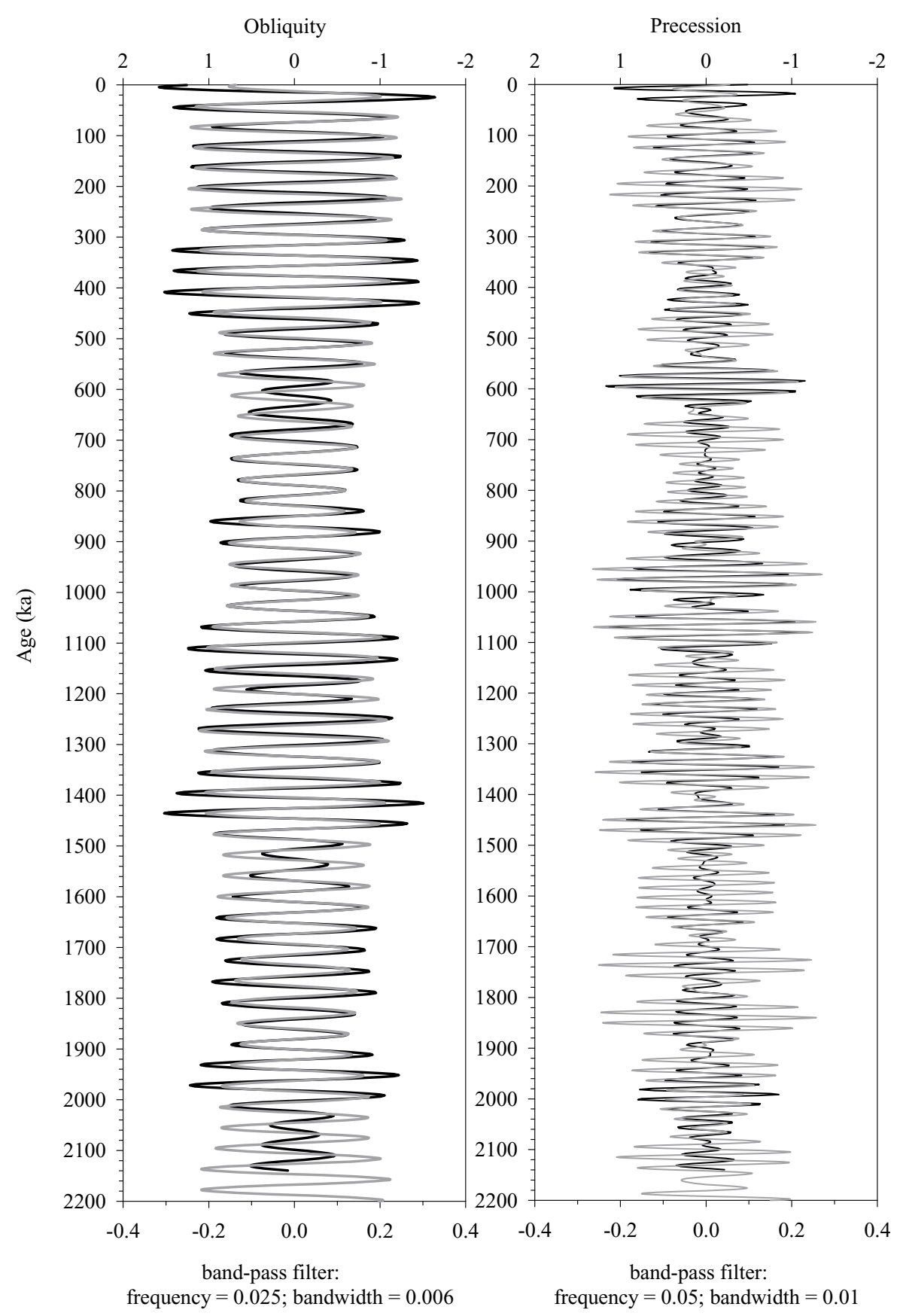

Fig. 5. The astronomically tuned $\delta^{18} \mathrm{O}$ curve from core MD972143 after band-pass filtering to extract its obliquity and precession components (solid lines). These filtered records are compared with the cycles from the target curve (gray lines) extracted using the same filters.

subchron (Mankinen et al., 1978). The two normal polarity episodes below the Olduvai subchron are considered to represent the Réunion subchron (McDougall and Watkins, 1973), although the earlier one, which falls within the reworked foraminiferal sandy layer, cannot be recognized with confidence.

\subsection{Oxygen isotope stratigraphy}

The $\delta^{18} \mathrm{O}$ record of core MD972143 is shown in Fig. 2(g). The numbering of oxygen isotope stages down to Stage $49(24.00 \mathrm{~m})$ was achieved in a straightforward manner by correlation with the composite $\delta^{18} \mathrm{O}$ record of cores $\mathrm{V} 19$ 30, ODP Sites 677 and 846 (hereinafter V677846), which is available from http://delphi.esc.cam.ac.uk/ coredata/v677846.html and is based on Shackleton and Pisias (1985) for V19-30, Shackleton et al. (1990) for ODP 677, and Shackleton et al. (1995) for ODP 846. Stage 20 is obscure in core MD972143 due to insufficient benthic specimens for oxygen isotope analysis. Stage 51 is also difficult to recognize probably because of the presence of an overlying tephra layer. However, using a nearly synchronous calcareous nannofossil datum, the first appearance of medium-sized Gephyrocapsa $(4-5.5 \mu \mathrm{m})$ that has been well determined at Stage 59/60 (Wei, 1993; Raffi et $a l ., 1993)$, we can assign the $\delta^{18} \mathrm{O}$ signal within the interval $26.00-26.60 \mathrm{~m}$ to these two stages since this biostratigraphic event has been precisely anchored at $26.34 \mathrm{~m}$ (Fig. 2(g); un- 


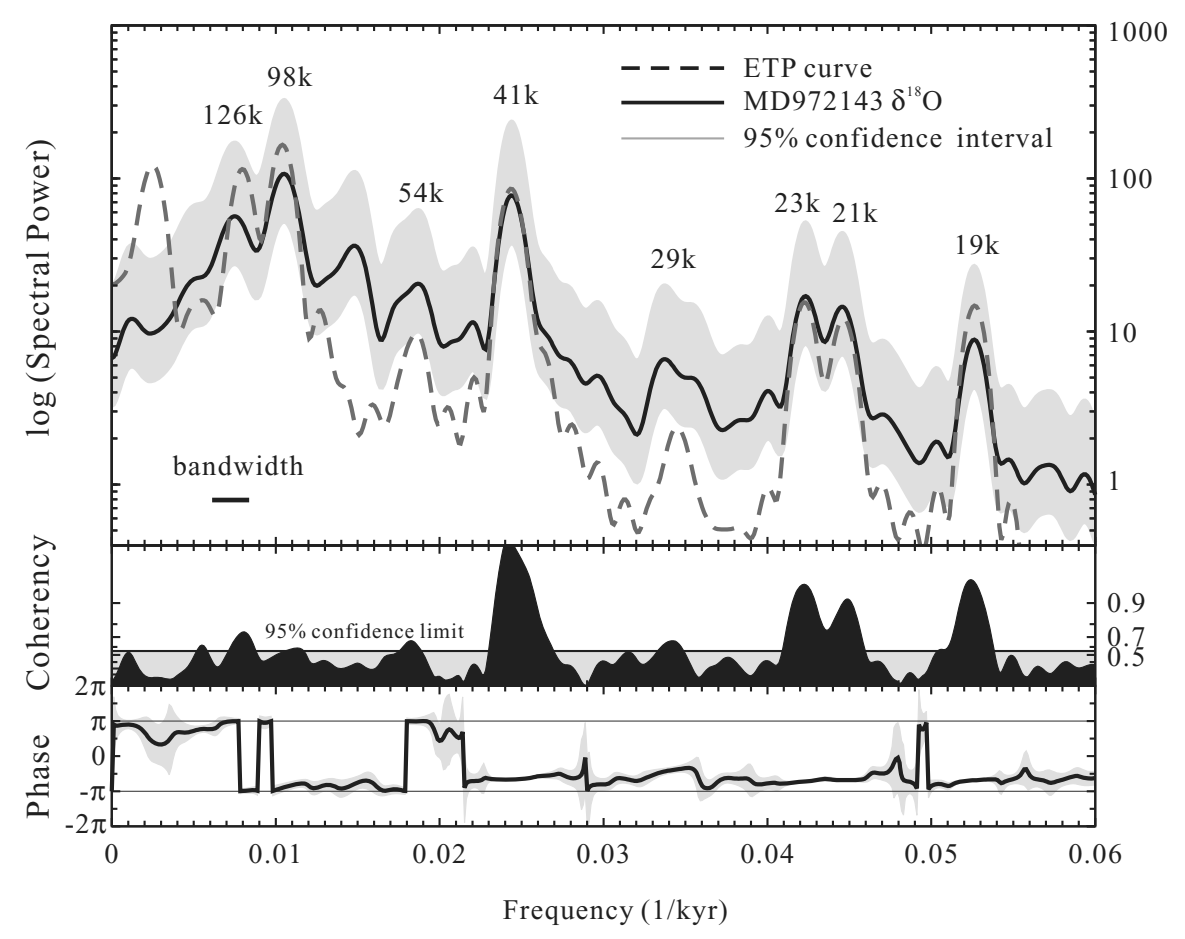

Fig. 6. Spectral power, coherency, and phase resulting from cross-spectral analysis of astronomically tuned $\delta^{18} \mathrm{O}$ of core MD972143 versus the ETP curve (see text for discussion).

published data of Horng). In addition, we are also confident in assigning the oxygen isotope record at $31.00-31.50 \mathrm{~m}$ to Stage 78 due to its highest values of $\delta^{18} \mathrm{O}$. Based on these observations, our $\delta^{18} \mathrm{O}$ record below $24.00 \mathrm{~m}$ correlates well with the V677846 reference curve and can be numbered down to Stage 81.

Checking specific stages at major magnetic reversal boundaries further validates our $\delta^{18} \mathrm{O}$ stage numbering. It is clear from Fig. 2(g) that stages 19, 27, 31, 63/64, and 71/72 correspond to the MBB, the top and base of the Jaramillo subchron, and the top and base of the Olduvai subchron, respectively, which are all in agreement with the results of Shackleton et al. (1990). Thus, core MD972143 has yielded a continuous oxygen isotope record down to Stage 81 . However, older stages below $32.91 \mathrm{~m}$ are difficult to identify because of the reworked foraminiferal sandy layer (Fig. 2(g)), and will not be discussed further.

\subsection{Astronomical chronology}

A first order chronology for core MD972143 was obtained by comparing our $\delta^{18} \mathrm{O}$ record with published astronomically tuned stable isotope data. In this study, we chose to use the V677846 composite record, because it fits well with our stable isotope record. We then performed a new astronomical tuning, making use of the astronomical solution La93 $_{(1,1)}$ of Laskar et al. (1993). Shackleton (2000) found that for the last $\sim 400 \mathrm{kyr}$, the best fitting target curve is one where climatic precession is lagged by $3 \mathrm{kyr}$, and obliquity by 7 kyr. Following this study, we constructed an artificial target curve by normalizing the climatic precession and obliquity of $\operatorname{La93}(1,1)$ (subtracting the mean and dividing by the standard deviation). Then, we added $3 \mathrm{kyr}$ to the initial astronomical age of precession, and $7 \mathrm{kyr}$ to the astronomical age of obliquity, and stacked together the lagged obliquity and precession series. At this step, we changed the sign of climatic precession values to stay consistent with Northern Hemisphere insolation. We then used the software package "AnalySeries" (Paillard et al., 1996) to match our flipped isotope curve to the target curve. Before this step, we adjusted the core depths by removing significant tephra layers. A total thickness of $0.93 \mathrm{~m}$ was subtracted (Fig. 2(a)). We inserted 56 age control points and assumed constant sedimentation rates between control points. Our new age model for core MD972143 is shown in Fig. 4, compared to the composite V677846 curve. Small changes are visible with respect to the V677846 curve, which are mostly caused by our use of a more recent astronomical calculation. It is clearly possible to obtain a far closer correlation between the MD972143 and V677846 $\delta^{18} \mathrm{O}$ curves, but, in order to obtain the most precise astronomically calibrated chronology, we have chosen to use the most recent astronomical target curve. Based on this age model and the control points, sedimentation rates between 2140 and $2000 \mathrm{ka}$ are relatively high, at an average of $2.0 \mathrm{~cm} / \mathrm{kyr}$ (Fig. 4). This high sedimentation rate seems to be realistic because this interval is just above the reworked foraminiferal sandy layer, which may imply that the unstable environments that caused the deposition of the sandy layer could have persisted to some extent up to $2000 \mathrm{ka}$. The sedimentation rates from 2000 to 340 ka are generally steady, at an average of $1.2 \mathrm{~cm} / \mathrm{kyr}$, and increase to about $2.6 \mathrm{~cm} / \mathrm{kyr}$ for the younger ages. The climatic precession and obliquity components of our data and the target curve are shown in Fig. 5, where it is clear that our age model is generally consistent with the target curve.

Finally, we performed a cross-spectral analysis (Blackman-Tukey) between the actual astronomical components (i.e., a stacking curve of eccentricity, obliquity 
Table 1. Comparison of magnetic reversal ages based on astronomical tuning and radiometric dating.

\begin{tabular}{|c|c|c|c|c|c|c|c|c|c|c|c|c|c|c|c|c|c|c|c|}
\hline \multirow[b]{2}{*}{$\begin{array}{l}\text { Magnetic } \\
\text { Reversal }\end{array}$} & \multirow[b]{2}{*}{$\begin{array}{c}\delta^{18} \mathrm{O} \\
\text { Stage }\end{array}$} & \multicolumn{10}{|c|}{ Astronomical Age (ka) } & \multicolumn{8}{|c|}{${ }^{40} \mathrm{Ar}{ }^{39} \mathrm{Ar} \quad$ Radiometric Age (ka) $\mathrm{K} / \mathrm{Ar}$} \\
\hline & & $\begin{array}{l}\text { This } \\
\text { Study }\end{array}$ & Sh90 & Hi91 & Ba94 & Ti94 & Ti95 & Lo96 & $\mathrm{Ta} 96$ & La97 & $\overline{\mathrm{Ch} 00}$ & $\overline{\mathrm{Ba} 92}$ & Ba93 & Tu94 & $\overline{S i 96}$ & $\mathrm{Ba} 00$ & $\overline{\mathrm{Si02}}$ & Ki99 & Ro00 \\
\hline Matuyama/Brunhes & 19 & 781 & 780 & & 775 & 780 & 780 & & 778 & 812 & $\begin{array}{l}773 / \\
775\end{array}$ & 783 & & & 779 & & 791 & & \\
\hline Kamikatsura & & & & & & & & & & & & & & & & & 899 & & \\
\hline $\begin{array}{l}\text { Santa Rosa top } \\
\text { Santa Rosa } \\
\text { Santa Rosa base }\end{array}$ & $\begin{array}{c}23 / 24 \\
24\end{array}$ & $\begin{array}{l}920 \\
925\end{array}$ & & & & & & & & & & & & & & & 936 & & \\
\hline Jaramillo top & 27 & 988 & 990 & & & 990 & 990 & & & 1001 & 990 & & & & & & 1001 & & \\
\hline Jaramillo base & 31 & 1072 & 1070 & & & 1070 & 1080 & & & 1072 & 1070 & & & & & & 1069 & & \\
\hline Punaruu & & & & & & & & & & & & & & & & & 1122 & & \\
\hline $\begin{array}{l}\text { Cobb Mt. top } \\
\text { Cobb Mt. } \\
\text { Cobb Mt. base }\end{array}$ & $\begin{array}{c}35 / 36 \\
36\end{array}$ & $\begin{array}{l}1173 \\
1185\end{array}$ & 1190 & & & & & & & & & & & 1186 & & & 1194 & & \\
\hline Olduvai top & $63 / 64$ & 1778 & 1770 & 1790 & & 1780 & 1770 & 1785 & & & & & & & & & & & \\
\hline Olduvai base & $71 / 72$ & 1945 & 1950 & 1950 & & 1940 & 1950 & 1942 & & & & & & & & & & & \\
\hline $\begin{array}{l}\text { Reunion II top } \\
\text { Reunion II } \\
\text { Reunion II base }\end{array}$ & $\begin{array}{c}80 / 81 \\
81\end{array}$ & $\begin{array}{l}2118 \\
2133\end{array}$ & & $\begin{array}{l}2140 \\
2150\end{array}$ & & & & $\begin{array}{l}2129 \\
2149\end{array}$ & & & & & $\begin{array}{l}2120 \\
2140 \\
2150\end{array}$ & & & $\begin{array}{l}2130 \\
2140\end{array}$ & & $\begin{array}{r}2020 \\
2070 \\
<2090\end{array}$ & 2090 \\
\hline
\end{tabular}

Sh90: Shackleton et al. (1990); Hi91: Hilgen (1991); Ba94: Bassinot et al. (1994); Ti94: Tiedemann et al. (1994); Ti95: Tiedemann and Haug (1995); Lo96: Lourens et al. (1996); Ta96: Tauxe et al. (1996); La97: Langereis et al. (1997); Ch00: Channell and Kleiven (2000).

Ba92: Baksi et al. (1992); Ba93: Baksi et al. (1993); Tu94: Turrin et al. (1994); Si96: Singer and Pringle (1996); Ba00: Baksi and Hoffman (2000); Si02: Singer and Brown (2002); Ki99: Kidane et al. (1999); Ro00: Roger et al. (2000).

(tilt) and flipped precession, called the ETP curve), rather than our target curve, and the isotope series in order to verify the tuning and the assumed phase relationship. High coherency values are evident in Fig. 6 at short eccentricity, obliquity, and climatic precession peaks. The phase relationship shows that obliquity and precession are out of phase with the astronomical components by $\sim 120^{\circ}$. Considering that high $\delta^{18} \mathrm{O}$ values correspond to minima in the insolation curve, this confirms the findings of Shackleton (2000) of phase lags of $180-120=60^{\circ}$ for both climatic precession and obliquity.

\subsection{Age estimates for geomagnetic reversals}

Using this new age model and assuming constant sedimentation rates between age control points, we obtained age estimates for the geomagnetic reversals within the Matuyama chron, which are presented in Fig. 4. The age uncertainties quoted are based on the stratigraphic uncertainty of magnetic reversals and the sedimentation rates. There are additional uncertainties that arise from the astronomical tuning process. These are difficult to quantify, but are likely to be small (within one precession cycle). For the MBB and the limits of the Jaramillo and Olduvai subchrons, our ages are consistent with previous astronomically tuned results (Shackleton et al., 1990; Hilgen, 1991; Bassinot et al., 1994; Tiedemann et al., 1994; Tiedeman and Haug, 1995; Lourens et al., 1996; Tauxe et al., 1996; Langereis et al., 1997; Channell and Kleiven, 2000). More significantly, astronomical ages can be obtained in this study for the boundaries of three short normal polarity episodes within the Matuyama chron. The two polarity episodes falling within stages 24 and 36, re- spectively, have age limits of 920-925 ka and 1173-1185 $\mathrm{ka}$, and the episode corresponding to Stage 81 has age limits of $2118-2133 \mathrm{ka}$. This last event is less certainly dated, because the oxygen isotope stratigraphy does not agree as well with previously obtained records, which might be related to disturbance in connection with the observed sandy layer. Nevertheless, our study has provided a nearly complete astronomical time framework for geomagnetic reversals within the Matuyama chron, although the ages of the lowermost polarity episode in Fig. 2(f) cannot be determined. For the following discussion and comparison with other astronomical and radiometric ages, our results are summarized in Table 1.

\section{Discussion}

\subsection{Lock-in depth of remanent magnetization}

It has been shown that sediments often acquire a remanent magnetization shortly after deposition (Kent, 1973). Hence, sedimentary records of magnetic reversals are generally shifted downward below the sediment-water interface, resulting in an offset (or so-called lock-in depth) between the records and the true positions of magnetic reversals. Estimating the lock-in depth of magnetic reversals is therefore crucial because large lock-in depths may cause errors in age determination. Most lock-in depth studies of reversals have focused on the MBB, but conclusions are still controversial, ranging from tens of centimeters (Burns, 1989; deMenocal et al., 1990) to only a few centimeters (Tauxe et al., 1996). Nevertheless, recent estimates for the MBB and its position relative to the $\delta^{18} \mathrm{O}$ record appear to be converg- 
ing (deMenocal et al., 1990; Bassinot et al., 1994; Tauxe et al., 1996; Channell and Kleiven, 2000). That is, the MBB should occur slightly after $\delta^{18} \mathrm{O}$ event 19.3 (782 ka) (Bassinot et al., 1994) and has an astronomical age of about $775-778 \mathrm{ka}$. This age is almost indistinguishable from the mean ${ }^{40} \mathrm{Ar} /{ }^{39} \mathrm{Ar}$ age of $779 \mathrm{ka}$ given by Singer and Pringle (1996), considering different age models used to obtain the MBB age (Table 1). As shown in Figs. 2(f) and 4, the observed MBB in core MD972143 is at $15.60 \pm 0.03 \mathrm{~m}$ and is astronomically dated at $781 \pm 3 \mathrm{ka}$. This MBB position is $3 \mathrm{~cm}$ above Stage $19.3(15.63 \mathrm{~m})$ and its age is close to the best-estimated MBB age of 775-778 ka. This implies that the offset or lock-in depth between the true and the observed MBB in core MD972143 is on the scale of a few centimeters.

To check this conclusion, we evaluated the age offset between the Australasian microtektite layer and the MBB, because it has been proposed that the deposition of the microtektite layer precedes the MBB by about $12 \pm 6 \mathrm{kyr}$ (Burns, 1989) or $15 \pm 5 \mathrm{kyr}$ (deMenocal et al., 1990). Following the technique of Burns (1989) to correct for bioturbation effects on microtektite positions, Lee and Wei (2000) moved the peak abundance of the microtektites at $15.71 \mathrm{~m}$ in core MD972143 (Fig. 2(g)) upwards by $2 \mathrm{~cm}$ to indicate its original depositional level $(15.69 \mathrm{~m})$. This datum event corresponds to an astronomical age of $790 \mathrm{ka}$ and hence has a time offset of $9 \pm 3$ kyr relative to the observed $\mathrm{MBB}$ (781 $\pm 3 \mathrm{ka})$. This supports the conclusion that the lock-in depth is fairly shallow for the MBB. Apparently, this conclusion can be extended to other reversal boundaries in core MD972143, because sedimentation rates (1-3 cm/kyr) and the lithology (except in the tephra layers) are relatively uniform.

\subsection{Correlation of short polarity episodes to the geo- magnetic polarity time scale}

The Cobb Mountain subchron and Kamikatsura polarity interval are two short normal polarity intervals that have been documented to precede and follow the Jaramillo subchron, respectively (Mankinen et al., 1978; Maenaka, 1983; Champion et al., 1988). However, based on ${ }^{40} \mathrm{Ar} /{ }^{39} \mathrm{Ar}$ dating and transitional paleomagnetic data from basaltic lava in Hawaii and Tahiti, Singer et al. (1999) reported that there are several geomagnetic reversals near the Jaramillo subchron. In addition to the Cobb Mountain subchron and Kamikatsura polarity interval, they identified two short normal polarity events, called the Santa Rosa and Punaruu polarity intervals. Recently, Singer and Brown (2002) gave an age of $899 \pm 6$ ka for the Kamikatsura polarity interval and re-dated the Santa Rosa event recorded in rhyolite domes of Valles Caldera, New Mexico, at $936 \pm 8$ ka (Table 1), which were originally dated by the K-Ar and ${ }^{40} \mathrm{Ar} /{ }^{39} \mathrm{Ar}$ methods (Doell et al., 1968; Spell and McDougall, 1992; Izett and Obradovich, 1994). This age interpretation is consistent with independent evidence. For example, Takatsugi and Hyodo (1995) pointed out that the age of the Kamikatsura polarity interval initially reported in Japan should be greater than the earlier estimate (0.85 Ma) by Maenaka (1983). Based on this nomenclature, our two normal polarity episodes, which have astronomical ages of 920-925 ka and 1173-1185 ka (Table 1), are most likely to represent the Santa Rosa polarity interval and Cobb Mountain subchron, respectively. It should be noted that our astronomically tuned ages for these two normal polar- ity episodes are slightly younger than those of Singer and Brown (2002). Although additional excursions/events could also exist near the Jaramillo subchron (Takatsugi and Hyodo, 1995; Singer et al., 1999), their durations are apparently short $(<1000 \mathrm{kyr})$ and are unlikely to correlate to the two episodes observed in core MD972143, which have durations of thousands of years.

It has been documented that the Réunion subchron occurred within the early Matuyama chron and is older than the Olduvai subchron by at least 0.1 Myr (McDougall and Watkins, 1973). Nevertheless, its polarity structure (i.e., single or double event) is still unclear and its age limits from different dating techniques are still not well reconciled (Hilgen, 1991; McDougall et al., 1992; Lourens et al., 1996; Baksi et al., 1993; Kidane et al., 1999; Baksi and Hoffman, 2000; Roger et al., 2000). Among these studies (Table 1), Kidane et al. (1999) proposed that the Réunion subchron recorded in lava flows in Ethiopia has a K-Ar age of $2.07 \pm 0.05 \mathrm{Ma}$, which is in agreement with earlier determinations (2.02 $\pm 0.02 \mathrm{Ma})$ of McDougall and Watkins (1973). In addition, they regarded the Réunion subchron as a double event characterized by large secular variation and full normal polarity in the earlier and later episodes, respectively. However, Baksi and Hoffman (2000) did not find evidence for a split Réunion subchron, because they obtained a similar ${ }^{40} \mathrm{Ar} /{ }^{39} \mathrm{Ar}$ age of $2.14 \pm 0.02 \mathrm{Ma}$ from the type sections on Réunion Island. According to our paleomagnetic data and astronomical time scale, we do not identify a double event in core MD972143 between 2.02 and 2.12 Ma (Figs. 2(d) (g) and 4). Instead, we observe a possible record of a double event during the age interval of 2.118-2.133 Ma (Réunion II) and below $\delta^{18} \mathrm{O}$ Stage 81 (Réunion I). Our estimated ages for the Réunion II subchron are 5-6\% older than the K-Ar age of McDougall and Watkins (1973) and are close to the ages of 2.13-2.15 Ma, which were given by other astronomical and radiometric dating techniques (Hilgen, 1991; McDougall et al., 1992; Lourens et al., 1996; Baksi et al., 1993; Baksi and Hoffman, 2000).

\section{Conclusions}

A high-quality magnetostratigraphy and oxygen isotope stratigraphy from IMAGES core MD972143 provide a clear relationship between geomagnetic reversals and the oxygen isotope stages in the Matuyama Chron. Through the astronomical tuning technique, we have established a nearly complete time framework for the geomagnetic reversals of this period, which confirms published results for the major polarity reversals of the Matuyama Chron, including the MBB, and the Jaramillo, Olduvai and Réunion II subchrons, respectively. In addition, we provide the first astronomically calibrated age estimates for the upper and lower reversals associated with the Cobb Mountain and Santa Rosa polarity intervals, respectively.

Acknowledgments. The authors are grateful to Andrew Roberts and Chih-An Huh for revising the manuscript. We also sincerely acknowledge Jim Channell and Masayuki Hyodo for their critical reviews and constructive comments. We thank Shu-Hua Chien and Yu-Sheng Yang for helping with X-ray analyses. This study is part of the Taiwan IMAGES Program supported by the National Science Council of the Republic of China (Grant NSC88-2116-M- 
001-021 to CSH and NSC88-2116-002-012 to KYW). We thank the scientific party and crew of the Marion Dufresne for coring in the west Philippine Sea on the IMAGES-III cruise. This is IESAS contribution number 799 .

\section{References}

Baksi, A. K. and K. A. Hoffman, On the age and morphology of the Réunion event, Geophys. Res. Lett., 27, 2997-3000, 2000.

Baksi, A. K., V. Hsu, M. O. McWilliams, and E. Farrar, ${ }^{40} \mathrm{Ar} /{ }^{39} \mathrm{Ar}$ dating of the Brunhes-Matuyama geomagnetic field reversal, Science, 256, 356357, 1992.

Baksi, A. K., K. A. Hoffman, and M. McWilliams, Testing the accuracy of the geomagnetic polarity time-scale (GPTS) at 2-5 Ma, utilizing ${ }^{40} \mathrm{Ar} /{ }^{39} \mathrm{Ar}$ incremental heating data on whole-rock basalts, Earth Planet. Sci. Lett., 118, 135-144, 1993

Bassinot, F. C., L. D. Labeyrie, E. Vincent, X. Quidelleur, N. J. Shackleton, and Y. Lancelot, The astronomical theory of climate and the age of the Brunhes-Matuyama magnetic reversal, Earth Planet. Sci. Lett., 126, $91-$ $108,1994$.

Berggren, W. A., F. J. Hilgen, C. G. Langereis, D. V. Kent, J. D. Obradovich, I. Raffi, M. E. Raymo, and N. J. Shackleton, Late Neogene chronology: New perspectives in high-resolution stratigraphy, Geol. Soc. Am. Bull., 107, 1272-1287, 1995.

Burns, C. A., Timing between a large impact and a geomagnetic reversal and the depth of NRM acquisition in deep-sea sediments, in Geomagnetism and Paleomagnetism, edited by F. J. Lowes et al., pp. 253-261, Kluwer Academic Publishers, Dordrecht, 1989.

Champion, D. E., M. A. Lanphere, and M. A. Kuntz, Evidence for a new geomagnetic reversal from lava flows in Idaho: Discussion of short polarity reversals in the Brunhes and late Matuyama polarity chrons, J. Geophys. Res., 93, 11667-11680, 1988

Channell, J. E. T. and H. F. Kleiven, Geomagnetic palaeointensities and astrochronological ages for the Matuyama-Brunhes boundary and the boundaries of the Jaramillo subchron: Palaeomagnetic and oxygen isotope records from ODP Site 983, Phil. Trans. R. Soc. Lond., A358, 1027 $1047,2000$.

Clement, B. M., D. V. Kent, and N. D. Opdyke, A synthesis of magnetostratigraphic results from Pliocene-Pleistocene sediments cored using the hydraulic piston corer, Paleoceanography, 11, 299-308, 1996.

Cui, Y. L., K. L. Verosub, and A. P. Roberts, The effect of maghemitization on large multi-domain magnetite, Geophys. Res. Lett., 21, 757-760, 1994.

deMenocal, P. B., W. F. Ruddiman, and D. V. Kent, Depth of postdepositional remanence acquisition in deep-sea sediments: A case study of the Brunhes-Matuyama reversal and oxygen isotopic Stage 19.1, Earth Planet. Sci. Lett., 99, 1-13, 1990.

Doell, R. R., G. B. Dalrymple, R. L. Smith, and R. A. Bailey, Paleomagnetism, potassium-argon ages, and geology of rhyolites and associated rocks of the Valles Caldera, New Mexico, Mem. Geol. Soc. Am., 116, 211-248, 1968.

Hilgen, F. J., Astronomical calibration of Gauss to Matuyama sapropels in the Mediterranean and implication for the geomagnetic polarity time scale, Earth Planet. Sci. Lett., 104, 226-244, 1991.

Horng, C.-S., A. P. Roberts, and W.-T. Liang, A 2.14-million-year astronomically-tuned record of relative geomagnetic paleointensity from the western Philippine Sea, J. Geophys. Res., 2002 (in press).

Izett, G. A. and J. D. Obradovich, ${ }^{40} \mathrm{Ar} /{ }^{39} \mathrm{Ar}$ age constraints for the Jaramillo normal subchron and the Matuyama-Brunhes geomagnetic boundary, $J$. Geophys. Res., 99, 2925-2934, 1994.

Kent, D. V., Post-depositional remanent magnetization in deep-sea sediment, Nature, 246, 32-33, 1973

Kidane, T., J. Carlut, V. Courtillot, Y. Gallet, X. Quidelleur, P. Y. Gillot, and T. Haile, Paleomagnetic and geochronological identification of the Réunion subchron in Ethiopian Afar, J. Geophys. Res., 104, 1040510419, 1999

Langereis, C. G., M. J. Dekkers, G. J. de Lange, M. Paterne, and P. J. M. van Santvoort, Magnetostratigraphy and astronomical calibration of the last 1.1 Myr from an eastern Mediterranean piston core and dating of short events in the Brunhes, Geophys. J. Int., 129, 75-94, 1997.

Laskar, J., F. Joutel, and F. Boudin, Orbital, precessional, and insolation quantities for the earth from $-20 \mathrm{Myr}$ to $+10 \mathrm{Myr}$, Astron. Astrophys. 270, 522-533, 1993.

Lee, M.-Y. and K.-Y. Wei, Australasian microtektites in the South China Sea and the West Philippine Sea: Implications for age, size and location of the impact crater, Meteorit. Planet. Sci., 35, 1151-1156, 2000.
Lourens, L. J., A. Antonarakou, F. J. Hilgen, A. A. M. van Hoof, C. Vergnaud-Grazzini, and W. J. Zachariasse, Evaluation of the PlioPleistocene astronomical timescale, Paleoceanography, 11, 391-413, 1996.

Maenaka, K., Magnetostratigraphic study of the Osaka Group, with special reference to the existence of pre- and post-Jaramillo episodes in the late Matuyama polarity epoch, Mem. Hanazono Univ., 14, 1-65, 1983.

Mankinen, E. A., J. M. Donnelly, and C. S. Gromme, Geomagnetic polarity event recorded at 1.1 m.y. B.P. on Cobb Mountain, Clear Lake volcanic field, California, Geology, 6, 653-656, 1978.

McDougall, I. and N. D. Watkins, Age and duration of the Réunion geomagnetic polarity event, Earth Planet. Sci. Lett., 19, 443-452, 1973.

McDougall, I., F. H. Brown, T. E. Cerling, and J. W. Hillhouse, A reappraisal of the geomagnetic polarity time scale to $4 \mathrm{Ma}$ using data from the Turkana Basin, east Africa, Geophys. Res. Lett., 19, 2349-2352, 1992.

Moskowitz, B. M., M. Jackson, and C. Kissel, Low-temperature magnetic behavior of titanomagnetites, Earth Planet. Sci. Lett., 157, 141-149, 1998.

Nenova, P. I., "Fe23": A computer program for calculating the number of $\mathrm{Fe}^{+2}$ and $\mathrm{Fe}^{+3}$ ions in minerals, Comput. Geosci., 23, 215-219, 1997.

Özdemir, Ö., D. J. Dunlop, and B. M. Moskowitz, The effect of oxidation on the Verwey transition in magnetite, Geophys. Res. Lett., 20, 1671-1674, 1993.

Paillard, D., L. Labeyrie, and P. Yiou, Macintosh program performs timeseries analysis, EOS Trans. AGU, 77, 379, 1996.

Raffi, I., J. Backman, D. Rio, and N. J. Shackleton, Plio-Pleistocene nannofossil biostratigraphy and calibration to oxygen isotope stratigraphies from Deep Sea Drilling Project Site 607 and Ocean Drilling Program Site 677, Paleoceanography, 8, 387-408, 1993

Raymo, M. E., W. F. Ruddiman, J. Backman, B. M. Clement, and D. G. Martinson, Late Pliocene variation in Northern Hemisphere ice sheets and North Atlantic deep water circulation, Paleoceanography, 4, 413446, 1989.

Roger, S., C. Coulon, N. Thouveny, G. Feraud, A. van Velzen, S. Fauquette, J. J. Cocheme, M. Prevot, and K. L. Verosub, ${ }^{40} \mathrm{Ar} /{ }^{39} \mathrm{Ar}$ dating of a tephra layer in the Pliocene Seneze maar lacustrine sequence (French Massif Central): constraint on the age of the Réunion-Matuyama transition and implications on paleoenvironmental archives, Earth Planet. Sci. Lett., 183, 431-440, 2000 .

Ruddiman, W. F., M. E. Raymo, D. G. Martinson, B. M. Clement, and J. Backman, Pleistocene evolution: Northern Hemisphere ice sheets and North Atlantic Ocean, Paleoceanography, 4, 353-412, 1989.

Shackleton, N. J., The 100,000-year ice-age cycle identified and found to lag temperature, carbon dioxide, and orbital eccentricity, Science, $\mathbf{2 8 9}$, 1897-1902, 2000

Shackleton, N. J. and N. G. Pisias, Atmospheric carbon dioxide, orbital forcing, and climate, in The Carbon Cycle and Atmospheric $\mathrm{CO}_{2}: \mathrm{Nat}$ ural Variations, Archean to present, edited by E. T. Sundquist and W. S Broeker, AGU Geophys. Monogr., 32, pp. 412-417, 1985.

Shackleton, N. J., A. Berger, and W. R. Peltier, An alternative astronomical calibration of the lower Pleistocene timescale based on ODP Site 677, Trans. R. Soc. Edinburgh: Earth Sciences, 81, 251-261, 1990.

Shackleton, N. J., S. Crowhurst, T. Hagelberg, N. G. Pisias, and D. A Schneider, A new Late Neogene time scale: Application to Leg 138 sites, Proc. ODP Sci. Results, 138, 73-101, 1995.

Singer, B. S. and L. L. Brown, The Santa Rosa event: ${ }^{40} \mathrm{Ar} /{ }^{39} \mathrm{Ar}$ and paleomagnetic results from the Valles rhyolite near Jaramillo Creek, Jemez Mountains, New Mexico, Earth Planet. Sci. Lett., 197, 51-64, 2002.

Singer, B. S. and M. S. Pringle, Age and duration of the Matuyama-Brunhes geomagnetic polarity reversal from ${ }^{40} \mathrm{Ar} /{ }^{39} \mathrm{Ar}$ incremental heating analyses of lavas, Earth Planet. Sci. Lett., 139, 47-61, 1996.

Singer, B. S., K. A. Hoffman, A. Chauvin, R. S. Coe, and M. S. Pringle, Dating transitionally magnetized lavas of the late Matuyama chron: Toward a new ${ }^{40} \mathrm{Ar} /{ }^{39} \mathrm{Ar}$ timescale of reversals and events, J. Geophys. Res. 104, 679-693, 1999.

Spell, T. L. and I. McDougall, Revisions to the Brunhes-Matuyama boundary and the Pleistocene geomagnetic polarity timescale, Geophys. Res. Lett., 19, 1181-1184, 1992.

Takatsugi, K. O. and M. Hyodo, A geomagnetic excursion during the late Matuyama chron, the Osaka Group, southwest Japan, Earth Planet. Sci. Lett., 136, 511-524, 1995.

Tauxe, L., T. Herbert, N. J. Shackleton, and Y. S. Kok, Astronomical calibration of the Matuyama-Brunhes boundary: Consequences for magnetic remanence acquisition in marine carbonates and the Asian loess sequences, Earth Planet. Sci. Lett., 140, 133-146, 1996. 
Tiedemann, R. and G. H. Haug, Astronomical calibration of cycle stratigraphy for site 882 in the Northwest Pacific, Proc. ODP Sci. Res., 145, 283-292, 1995.

Tiedemann, R., M. Sarnthein, and N. J. Shackleton, Astronomic timescale for the Pliocene Atlantic $\delta^{18} \mathrm{O}$ and dust flux records of Ocean Drilling Program site 659, Paleoceanography, 9, 619-638, 1994.

Turrin, B. D., J. M. Donnelly-Nolan, and B. C. Hearn, ${ }^{40} \mathrm{Ar} /{ }^{39} \mathrm{Ar}$ ages from the rhyolite of Alder Creek, California: Age of the Cobb Mountain normal-polarity subchron revisited, Geology, 22, 251-254, 1994.
Van Velzen, A. J. and J. D. A. Zijderveld, Effects of weathering on singledomain magnetite in Early Pliocene marine marls, Geophys. J. Int., 121, 267-278, 1995.

Wei, W., Calibration of upper Pliocene-lower Pleistocene nannofossil events with oxygen isotope stratigraphy, Paleoceanography, 8, 85-99, 1993.

C.-S. Horng (e-mail: cshorng@earth.sinica.edu.tw), M.-Y. Lee, H. Pälike, K.-Y. Wei, W.-T. Liang, Y. Iizuka, and M. Torii 